\title{
Pendidikan Perdamaian Bagi Calon Guru Sekolah Dasar Di STKIP Weetebula
}

\author{
Heronimus Delu Pingge ${ }^{1}$
}

${ }^{I}$ Prodi Pend. IPS Universitas Pendidikan Indonesia

*Heronimus Delu Pingge: Prodi Pend.IPS Universitas Pendidikan Indonesia; Email: pinggeroni@gmail.com

\begin{abstract}
Indonesia merupakan negara yang memiliki kecenderungan terjadinya konflik yang tinggi dikarenakan keadaan masyarakat yang plural dan memiliki berbagai karakteristik. Agar konflik tidak mengakibatkan kekerasan yang berujung pada perpecahan sosial dan rusaknya tataran sosial, maka konflik perlu dikelola dengan tepat dan terkontrol sehingga tercipta kedamaian. Menyikapi hal tersebut Sekolah Tigggi Keguruan Ilmu Pendidikan (STKIP) Weetebula mempersiapkan calon guru dengan kemampuan mengelola konflik sebagai dasar untuk menciptakan dan mengajarkan pendidikan perdamaian. Adapun masalah penelitian adalah: apakah isi matakuliah Manajemen Konflik pada program studi pendidikan guru sekolah dasar (PGSD) di STKIP Weetebula berkaitan erat dengan tujuan pendidikan kedamaian?. Tujuan penelitian untuk mengkaji isi matakuliah Manajemen Konflik pada program studi PGSD di STKIP Weetebula dari aspek: pertama, posisi matakuliah manajemen konflik dalam kurikulum program studi PGSD; Kedua, pokok-pokok materi perkuliahan dalam setiap pertemuan, ketiga metode perkuliahan, media dan sumber rujukan matakuliah manajemen konflik. Data dihimpun dengan cara observasi, wawancara dan dokumantasi. Pengolahan data dilakukan melalui tiga tahap, yaitu reduksi data, penyajian dan pengambilan kesimpulan sebagai keputusan. Hasil penelitian menunjukkan bahwa matakuliah manajemen konflik dipelajari oleh mahasiswa pada semester dua dan masuk dalam kelompok matakuliah keahlihan berkarya (MKB). Ada lima belas topik materi yang dipelajari mahasiswa dengan metode perkuliahan yang bervariasi dan dosen yang mengajar berlatar belakang pendidikan bimbingan dan konseling dan Manejem Pendidikan.
\end{abstract}

Keywords:Calon Guru, Sekolah Dasar, Pendidikan Perdamaian

\section{Pendahuluan}

Sekolah Sekolah adalah suatu lembaga yang mempunyai peran strategis terutama mendidik dan menyiapkan sumber daya manusia yang berkualitas dalam memegang estafet generasi sebelumnya. Keberadaan sekolah sebagai sub sistem tatanan kehidupan sosial, menempatkan lembaga sekolah sebagai bagian dari sistem sosial. Sebagai bagian dari sistem dan lembaga sosial, sekolah harus peka dan tanggap dengan harapan dan tuntutan masyarakat sekitarnya. Sekolah diharapkan menjalankan fungsinya dengan mencerdaskan kehidupan bangsa dengan optimal dan mengamankan diri dari pengaruh negatif lingkungan sekitar (Lestari, M, 2017:268).

Lingkungan sekolah yang positif dan kondusif akan dapat menciptakan kondisi sekolah seperti diatas, dan tidak akan terlepas dari peran seorang guru. Sedangkan untuk menjadi seorang guru itu sendiri tidaklah gampang, memerlukan kemampuan keahlihan khusus. Hal tersebut bisa dilihat dari tugas dan tanggung jawab guru yang harus menyelesaikan berbagai macam administrasi sekolah dan bukan hanya bertugas mentransfer pengetahuan, tetapi lebih dari itu ia harus dapat membentuk pribadi siswa secara utuh. Untuk itu, guru harus berkomitmen dan bersedia melakukan pekerjaannya dengan ikhlas dan ekstra sehingga 
bisa menjadi seorang guru yang profesional (Arifin, Zainal; 2013).

Lembaga Pendidikan Tenaga Kependidikan (LPTK) mempunyai peran yang sangat penting untuk menyediakan guru yang mampu mendidik peserta didik untuk menjadi individu yang utuh dan mandiri. LPTK harus mampu pula membekali calon guru untuk mempunyai kemampuan dalam melakukan pendidikan resolusi konflik disekolah. Pendidikan resolusi konflik sendiri di mulai dari sekolah dasar sampai dengan sekolah menengah belum terakomodasi dalam kurikulum (Wulandari, 2010). Bila dicermati di Indonesia penduduknya sangat plural, baik ras, agama, bahasa, adat-istiadat, warna kulit, dan lain sebagainya. Keadaan tersebut akan membuat Indonesia rentan terjadinya konflik. Sejarah program resolusi konflik di sekolah pertama kali muncul pada awal 1970-an, dipicu oleh meningkatnya kepedulian para pendidik dan orang tua tentang kekerasan di sekolah. Kota New York adalah kota yang pertama memperkenalkan ide-ide resolusi konflik ke sekolah-sekolah di A.S. Dengan dibentuknya pendidik untuk tanggung jawab sosial pada tahun 1981 dan asosiasi nasional untuk mediasi dalam pendidikan pada tahun 1984 , gerakan untuk resolusi konflik di sekolah menjadi lebih terorganisir (Girard,Kathryn. \& Susan J. Koch, 1996).

Menurut Heydenberk, dkk dalam James \& Owens (2004) Pendidkan resolusi konflik mengajarkan kepada siswa cara memecahkan masalah sosial yang dihadapi secara lebih positif sehingga menghindarkan siswa dari perilaku bullying, mengajarkan siswa meregulasi diri, mengontrol perilaku dan membuat pilihan yang tepat, dan meningkatkan harga diri dan rasa aman ketika berada di sekolah. Dengan kata lain bahwa pendidikan resolusi konflik menyediakan keterampilan yang mendukung partisipasi demokratis dan pengalaman konflik produktif yangmembangun tatanan sosial yang stabil (Girard, Kathryn. \& Susan J. Koch, 1996).

Sekolah atau dalam hal ini guru yang melakukan pendidikan resolusi konflik disekolah terlebih dahulu perlu harus memahami resolusi konflik itu sendiri. Girard, Kathryn. \& Susan J. Koch (1996) menyatakan bahwa lembaga pendidikan guru juga harus memutuskan posisi resolusi konflik dalam kurikulum pendidikan calon guru. Mengingat berbagai cara penyelesaian konflik dapat diterapkan di sekolah, setiap anggota fakultas atau kelompok harus menentukan apa yang ingin mereka capai sehubungan dengan kurikulum resolusi konflik dan yang mereka yakini. Sama seperti resolusi konflik dapat diintegrasikan ke sekolah-sekolah dalam banyak cara yang berbeda, maka resolusi konflik dapat diintegrasikan ke dalam program persiapan guru. Ini dapat dimasukkan sebagai bagian dari persiapan prajabatan, program pascasarjana, atau pelatihan dalam jabatan. resolusi konflik dapat diajarkan sebagai bagian dari metode, manajemen kelas, kesehatan, konseling, komunikasi, atau kelas administrasi.

Gambaran tugas guru serta kedudukan pendidikan resolusi konflik disekolah diatas menjadi perhatian khusus dari Sekolah Tigggi Keguruan Ilmu Pendidikan (STKIP) Weetebula untuk mempersiapan calon guru dengan kemampuan mengelola konflik sebagai dasar untuk menciptakan dan mengajarkan pendidikan perdamaian di Sekolah. Hal ini yang mendorong dilakukan penelitian dengan tujuan penelitian untuk mengkaji isi matakuliah Manajemen Konflik pada program studi PGSD di STKIP Weetebula dari aspek: pertama, posisi matakuliah manajemen konflik dalam kurikulum program studi PGSD; Kedua, pokok-pokok materi perkuliahan dalam setiap pertemuan, ketiga metode perkuliahan, media dan sumber rujukan matakuliah manajemen konflik.

\section{Metode Penelitian}

Penelitian yang dilakukukan dengan menggunakan penelitian kualitatif dengan metode atau jenis pendekatan studi pustaka (Library research). Studi kepustakaan merupakan suatu studi yang digunakan dalam mengumpulkan informasi dan data dengan bantuan berbagai macam material yang ada di perpustakaan seperti dokumen, buku, majalah, kisah-kisah sejarah, dsb (Mardalis:1999).Studi kepustakaan juga dapat mempelajari berbagai buku referensi serta hasil penelitian sebelumnya yang sejenis yang berguna untuk mendapatkan landasan teori mengenai masalah yang akan diteliti (Sarwono:2006). Studi kepustakaan juga berarti teknik pengumpulan data dengan melakukan penelaahan terhadap buku, literatur, catatan, serta berbagai laporan yang berkaitan dengan masalah yang ingin dipecahkan (Nazir:1988). 
Sumber data berupa modul perkuliahan Manajemen Konflik, dokumen kurikulum prodi PGSD STKIP Weetebula. Data dianalisis dengan metode analisis isi (Content Analysis). untuk memperkuat data yang dianalisis dilakukan wawancara pada dosen yang mengajarkan matakuliah Manajemen Konflik.

\section{Hasil dan Pembahasan}

Hasil

Kurikulum Prodi PGSD STKIP Weetebula menyediakan satu matakuliah yang bertujuan menyiapkan calon guru yang bisa mengatasi dan mencegah konflik disekolah, masyarakat maupun bagi diri sendiri. Nama mata kuliah tersebut adalah Manajemen Konflik. Matakuliah Manajemen Konflik (MMK) memiliki bobot 2 SKS dengan kode Matakuliah MKB1601202 matakuliah tersebut termasuk kelompok Matakuliah Keahlian Berkarya (MKB), Kelompok bahan kajian untuk mendukung keahlian pendidikan PGSD. Deskripsi matakuliah manajemen konflik dalam dokumen kurikulum prodi PGSD STKIP Weetebula adalah "Mahasiswa dapat memahami konsep dasar konflik dan manajemen konflik, jenis dan pengaruh konflik, asumsi dan proses konflik, gaya manajemen konflik, resolusi konflik". Tercatat dalam jadwal mengajar dan dokumen lainnya bahwa matakuliah manajemen konflik diajarkan oleh dosen yang berlatar belakang keilmuan Bimbingan dan Konseling, Psikologi, dan Manajemen Pendidikan. Pada tahun akdemik 2017/2018 dihasilkan modul Matakuliah yang diberi judul "Transformasi Konflik. Buku Panduan untuk pengajaran dosen di STKIP Weetebula". modul disusun bersama oleh tim pengajar matakuliah manajemen konflik dengan pendampingan dari Ibu Brigitte L. Ehrich, M.A pakar Peace and confict yang berkebangsaan Jerman.

Mahasiswa akan memprogramkan matakuliah manajemen konflik pada semester II. Jumlah pertemuan tatap muka yang dirancang dalam modul sebanyak lima belas kali dan dua kali ujian (UAS dan UTS). metode perkuliahan didominasi dengan diskusi kelompok kecil untuk memprektikkan model-model resolusi konflik. Durasi waktu yang dibutuhkan setiap pertemuan 150 menit. Pokok materi perkuliahan setiap pertemuan dapat dilihat pada tabel dibawah ini:

\section{Tabel 1. Pokok Materi Perkulian Manajemen Konflik}

\begin{tabular}{ll}
\hline Pertemuan & Pokok Materi \\
\hline 1 & Definisi kata kunci \\
2 & Analisis Konflik I: Peta Pelaku \\
3 & Kebutuhan Dasar \\
4 & Analisis Pelaku \\
5 & Mengatasi Penyebab Konflik \\
6 & Konflik sebagai Proses yang Dinamis: \\
& Eskalasi Konflik \\
7 & Komunikasi sebagai Kunci untuk \\
& Transformasikan Konflik \\
8 & Komunikasi II: Komunikasi tanpa \\
& Kekerasan I \\
9 & Komunikasi III: Komunikasi tanpa \\
& Kekerasan II \\
10 & Mendengarkan-seni istimewa untuk \\
13 & Transformasi Konflik \\
11 & Mediasi I \\
& Mediasi II: Tahapan III \\
& Mediasi III: Tahapan IV dan V \\
& Kerohanian Sikap Perdamaian \\
& Transformasi Besar: Guru sebagai \\
&
\end{tabular}

Untuk UTS dan UAS berupa ujian tertulis dengan soal analisis kasus atau masalah sosial dan mahasiswa harus menganalisis dan menyelesaikan berdasarkan metode resolusi konflik yang sudah diperkenalkan dalam perkuliahan. Referensi atau buku sumber yang digunakan diantaranya adalah, 1) Konflikt transformation durch Gütekraft: Interpesonale Veränderungsprozesse karangan Bläsi, B, 2) Why civil resistance works. The strategic logic of conflict karangan Chenoweth, E. \& Stephan, M. J, 3) Gewaltfreier Aufstand. Alternative zum Bürgerkrieg karangan Ebert, T. 4) Friedens- und Konfliktarbeit karangan Ehrich, B, 5), People, Peace and Power: Conflict Transformation in Action karangan Francis, D. 6) Nonviolence and Peace Psychology. Intrapersonal, Interpersonal, Societal, and World Peace karangan Mayton II, D. M 7) Mediation. Ein Lehrbuch auf psychologischer Grundlage karangan Montada, L. \& Kals, E, 8) Miteinander Reden karangan Schulz von Thun, F, 10) Menschliche Kommunikation. Formen, Störungen, Paradoxien karangan Watzlawick, P., Beavin, J.H. \& Jackson, D, 11) 
Konflik dan Manajemen Konflik. Teori, Aplikasi, dan Penelitian karangan Wirawan, dan 12) (1983). Die Gewaltlosigkeit Jesu-eine Kraft, karangan Goss, J. \& Goss-Mayr, H. die Frieden schafft.

\section{Pembahasan}

Matakuliah Manajemen Konflik (MMK) menjadi salah satu matakuliah dalam kelompok matakuliah keahlihan berkarya (MKB). MMK dirasa perlu oleh program studi PGSD STKIP Weetebula karena lulusan Prodi PGSD STKIP Weetebula akan bekerja ditengah masyaraktat yang multikultural dan perlu keterampilan menyelesaikan konflik yang terjadi disekolah maunpun untuk mengajarkan cara menyikapi konflik dan mencegah konflik pada peserta didik.

Pada tahun akademik 2017/2018 semester genap para dosen yang mengajar MMK mendapat pendampingan dari pakar peace and conflik. Para dosen dilatih terlebih dahulu untuk mengetahui topik-topik yang dianggap perlu untuk diajarkan pada mahasiswa. Pada tabel 1 diatas dapat dilihat topik-topik pembahasan setiap pertemuan dan merupakan hasil dari pendampingan serta menghasilkan modul perkuliahan untuk dosen. Modul tersebut merupakan rangkuman dari bukubuku sumber yang digunakan oleh dosen.

Kegiatan perkuliahannya membutuhkan waktu 150 menit. Sedangkan metode yang digunakan pada awal perkuliahan adalah metode ceramah, sebagai pengantar matakuliah dan untuk memperkenalkan model-model yang berkaitan dengan MMK. Selanjutnya mahasiswa lebih banyak bekerja atau mempraktikkan model ataupun berdiskusi dalam kelompok kecil. Dari topik-topik pertemuan dalam MMK diatas dikelompokkan menjadi empat topik utama yakni pemahaman akan konlik, keterampilan mediasi, komunikasi sebagai dasar perdamaian, pendekatan religius atau agama dalam pendidikan resolusi konflik. Empat topik utama tersebut akan dijabarkan dibawah ini.

\section{a. Pengenalan Akan Konflik}

Pada awal kegiatan pembelajaran para mahasiswa diperkenalkan dan mengetahui konflik yang ada dilingkungan mereka dengan cara bermain peran tentang konflik yang pernah mereka alami ataupun diamati. Dengan bermain peran mahasiswa membuat definisi konflik seperti yang dialami. Dosen memperkenalkan definisi konflik menurut pandangan ahli-ahli dari sumber yang tersedia. Pada pertemuan ini juga mahasiswa diperkenalkan tentang efek dari kekerasan dan bentuk-bentuk kekerasan (kekerasan langsung, struktural dan kultural). Mahasiswa perlu mengetahui konsep "Perdamaian", bahwa perdamaian merupakan sikap mencegah konflik dan menyelesaikan konflik.

Mahasiswa diperkenalkan bahwa faktor penyebab konflik dan akibat dari konflik. Metode yang digunakan adalah dengan memperkenalkan kebutuhan manusia dari Abraham Maslow dan menurut J. Burton (1990). Mahasiswa mendiskusikan dalam kelompok kecil "bila kebutuhan tidak tercapai berdasarkan dua ahli tersebut, konflik yang bisa timbul seperti apa?". Dibawah ini bisa dilihat bagan kebutuhan menurut Abraham Maslow dan menurut J. Burton.

Gambar 1.

Teori kebutuhan Abraham Maslow

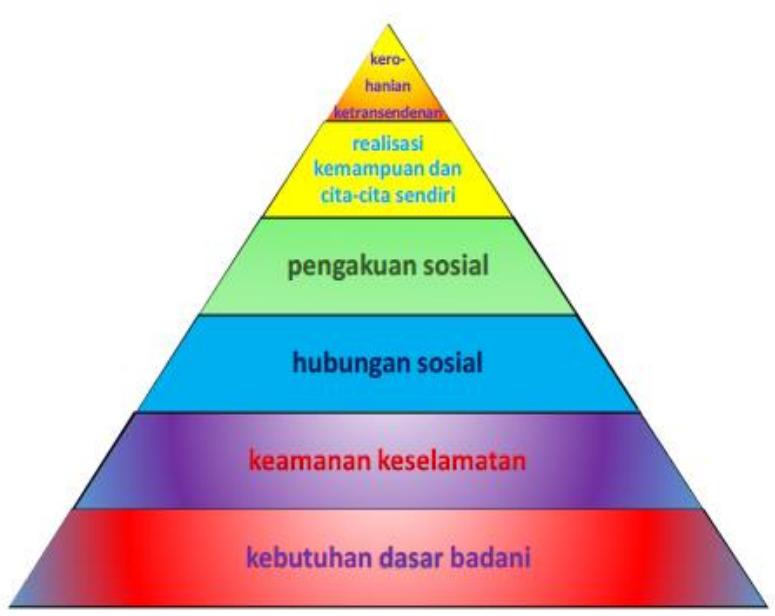

Gambar 2. Teori kebutuhan J. Burton 


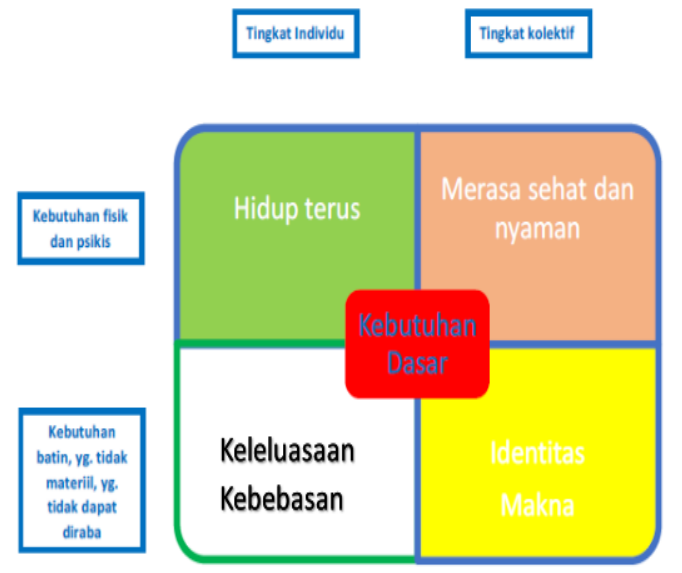

Diperkenalkan juga metode "pohon konflik". Metode "pohon konflik" mengajarkan mahasiswa untuk bisa membantu menemukan sebab dan akibat konflik. Akar-akar melambangkan penyebab-penyebab konflik, dahan, cabang, ranting dan daun melambangkan akibat, efek dan dampak konflik. Dibawah ini bisa lihat seorang mahasiswa sedang menyajikan hasil kerja kelompok tentang pohon konflik.

Gambar 3. Seorang Mahasiswa Sedang mempraktekkan Pohon Konflik

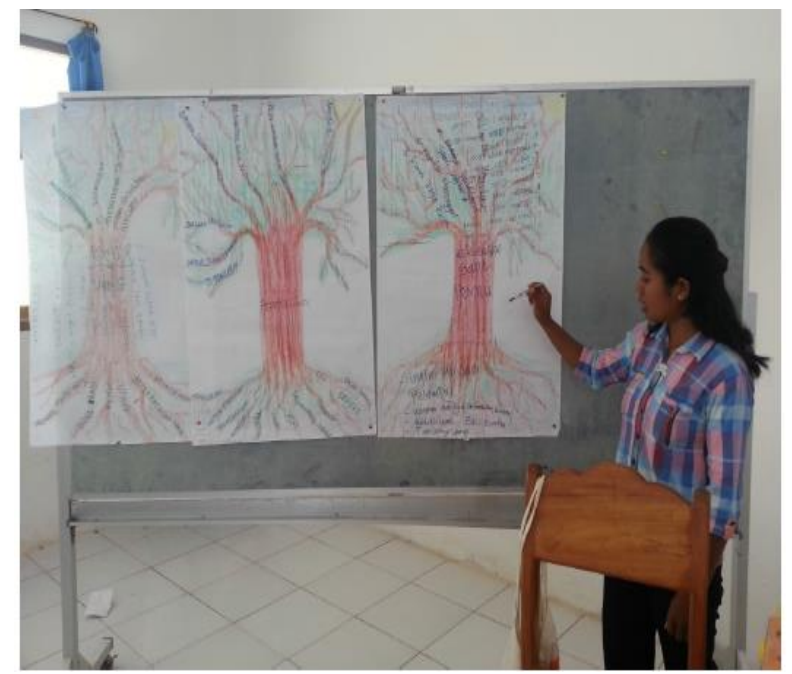

\section{b. Keterampilan Mediasi}

Pada bagian ini mahasiswa diperkenalkan cara-cara menjadi mediator yang baik. Lima pertemuan yang dibutuhkan untuk memperkenalkan model-model yang berkaitan dengan keterampilan mediasi. Ada model peta pelaku, Analisis kepentingan pelaku, dan proses melakukan mediasi Model "Peta Pelaku" mengajarkan mahasiswa untuk mampu menganalisa pelakupelaku yang terlibat dalam konflik yang terjadi serta pola hubungan para pelaku. Ini merupakan keterampilan bila seorang menjadi mediator. Mahasiswa diperkenalkan cara-cara membuat peta pelaku dengan memperkenalkan simbol-simbol yang dalam yang bisa dipakai dalam menganalisis para pelaku.

Setelah mahasiswa membuat peta pelaku maka diperkenalkan model "kepentingan pelaku". Mahasiswa dilatih untuk menganalisis konflik dengan memikirikan atau menganalisa kepetingan masing-masing pelaku konflik. Dibawah ini dapat dilihat ketika mahasiswa mempraktekkan model "kepentingan pelaku" dalam kelompok kecil.

Gambar 4. Mahasiswa mempraktekkan model analisis kepentingan

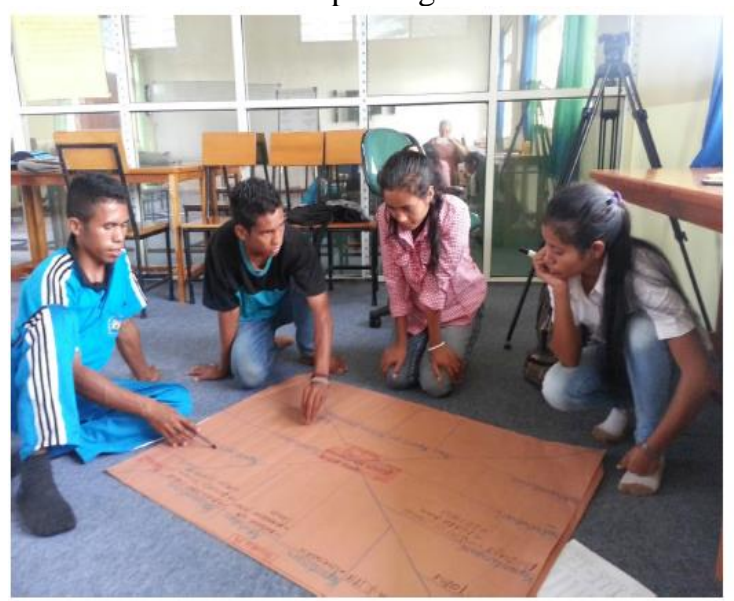

Proses melakukan mediasi dalam menyelesaikan konflik, mahasiswa diperkenalkan langkah-langkah mediasi L. Montada \& E. Kals (2007), mahasiswa dengan arahan dosen berlatih dengan melakukan rekayasa konflik dengan mengikuti langkah-langkah mediasi tersebut. Adapun model langkah model mediasi L. Montada \& E. Kals meliputi lima langkah, yakni;1. Persiapan, 2. Analisa Konflik, 3. Resolusi Konflik yang produktif, 4. Persetujuan Mediasi, dan 5. Evaluasi

\section{c. Komunikasi Sebagai Dasar Perdamaian}

Komunikasi bisa menyebabkan konflik dan juga sebagai sarana atau kemampuan untuk melakukan mediasi. Mahasiswa diperkenalkan bahwa komunikasi sebagai kunci dalam resolusi konflik dan pola komunikasi tanpa kekerasan atau 
konflik. Unsur lain juga yang perlu dilatih pada mahasiswa terkait pendidikan resolusi konflik adalah "kemampuan mendengarkan merupakan seni untuk resolusi konflik.

Pola perkuliahanya adalah mahasiswa diperkenalkan tentang model komonikasi dan mempraktekkan secara langsung dikelas dalam kelompok kecil atau berpasangan dengan mengikuti pola komunikasi dalam model yang diperkenalkan. Kunci dari komunikasi adalah menerima kabar/informasi dengan benar sesuai dengan maksudnya.

Mahasiswa dilatih supaya bisa mendengarkan dengan baik dan menyampaikan keinginan dengan benar agar tidak keliru ditanggapi oleh pendengar. Kemampuan berkomunikasi tampa kekerasan diperkenalkan kepada mahasiswa sebagai modal untuk mencegah konflik dan modal dalam melakukan mediasi. Model yang diperkenalkan adalah pola komunikasi dari "Model Komunikasi Rosenberg". mahasiswa dilatih dengan mempraktikkan didalam kelas secara berpasangan dengan menerapkan model komunikasi Rosenberg yang terdiri dari empat langkah. Yakni; 1. Observasi, 2. Perasaan, 3. Kebutuhan, dan 4. Permintaan. Dari empat langkah tersebut ada kata kunci yang diucapkan baik untuk mengkomunikasikan keinginan ataupun mendengarkan dengan efektif denngan menyampaikan ulang maksud dari lawan bicara. Diakhir perkuliahan mahasiswa diperkenalkan katakata yangdapat mengungkapkan perasaan individu.

\section{Tabel 2. Kata kunci dalam komunikasi tampa kekerasan}

1. Observasi: "Ketika saya mengamati(melihat, mendengar...)..."

2. Perasaan: "saya merasa..."

3. Kebutuhan: "karena sayamembutuhkan..."

4. Permintaan: "dan saya mohon Anda untuk..."

\section{d. Pendekatan Religius atau Agama dalam Pendidikan Resolusi Konflik}

Sertiap agama pasti mengajarkan kebaikan dan prilaku saling memaafkan.Pendidikan resolusi konflik perlu juga memperhatikan isu-isu kebaikan dari agama untuk dijadikan sebagai pencegah konflik dan menyelesaikan konflik.Ada dua pertemuan yang dilakukan untuk memperkenalkan pendekatan religius dalam pendidikan resolusi konflik bagi calon guru pada prodi PGSD STKIP Weetebula.Tidak secara langsung melakukan pendekatan pada agama tertentu dalam pendidikan resolusi konflik, tetapi menggunakan teori-teori dari tokoh perdamaian dan pakar pendidikan perdamaian.Ada tiga teori perdamaian yang diperkenalkan pada mahasiswa.Mahasiswa mengkaji nilai-nilai kedamaian dalam agama masing-masing dan dikaitkan dengan teori kedamaian. Dibawah ini tiga teori tersebut akan diuraikan.

Pertama teori Teixera.Dengan teori Teixeira tentang hubungan saling bergantung (interkoneksi) dipusat.Pikiran dan perbuat merupakan tujuan dari perdamaian, baik berdamai dengan diri sendiri, orang lain, dan Tuhan.Di lingkaran luar ada pendidikan dan pengasuhan yang memajukan perdamaian, sistem penghargaan dalam masyarakat dan sistem politis dan ekonomis, baik perjuangan sosial (politis) dan konfrontasi maupun resolusi konflik.Dibawah ini dapat dilihat bagan/pola perdamian dari teori Teixera.

Kedua Model oleh Brenes, model yang dikembangkan dalam rangka program perdamaian oleh PBB. Pusat lingkaran konsentris perdamaian. Perdamaian mengembangkan tiga bagian: 1) perdamaian dengan tubuh dan diri sendiri, dalam hati dan pikiran, 2) kesehatan untuk semua, yang berarti partisipasi politis dan sosial, budaya demokrasi dan perdamaian dengan orang lain dan 3) keseimbangan alam dengan keragaman hayati, kesadaran ekologis dan perdamaian dengan alam. Model Brenes lebih kompleks dapripada model dari seperti model Teixeira.

Ketiga: Teori dan praktek Mohandas Gandhi. Pendekatan yang holistik, karena sikap dan kegiatan tanpa kekerasan bersangkut dan memedulikan semua bidang kehidupan: sistem politis, ekonomis dan ekologis, kehidupan sosial dan terlebihlagi individu. Inti dari pandangan politik tanpa kekerasan yang diperkenalkan Gandhi adalah makna kedua dari istilah satyagraha. Sebagaimana telah didiskusikan sebelumnya, makna pertama satyagraha berarti "berpegang pada kebenaran". Dari perspektif kedua satyagraha mengandung makna tindakan tanpa kekerasan dalam rangka membawa keadilan sosial atau sarvodaya. Gandhi (1957/1927) menyebut pihakpihak yang mempraktikkan satyagraha sebagai 
satyagrahi. Sepanjang hidupnya, Gandhi terus mengembangkan berbagai strategi atau bentuk satyagraha yang ia anggap sebagai "percobaan dengan kebenaran". Tujuan dari setiap satyagraha bervariasi mulai dari hak-hak kaum tertindas seperti wanita dan kelompok hina-dina, perpajakan yang tidak adil, kemandirian orang-orang India, hingga kemerdekaan India dari Britania Raya.

Meskipun secara umum prosesnya secara induktif, prinsip-prinsip satyagraha semakin dimurnikan oleh Gandhi selama lebih dari 50 tahun di Afrika Selatan dan India. Bondurant (1965) menyimpulkan aturan-aturan dasar dari tindakan politis satyagraha sebagai berikut; 1) Kemandirian setiap waktu, 2) Inisiatif para satyagrahi, 3) Perluasan tujuan, strategi dan taktik dari kampanye, 4) Pengurangan tuntutan hingga nilai minimal yang konsisten dengan kebenaran, 5) Perkembangan progresif dari gerakan tersebut melalui langkahlangkah dan tahap-tahap yang telah ditentukan sesuai dengan situasi, 6) Pemeriksaan kelemahan dalam kelompok satyagraha, 7) Pencarian berkelanjutan akan kesempatan untuk bekerjasama dengan pihak lawan secara terhormat, 8)Menolak untuk melepaskan hal-hal yang sangat penting dalam negosiasi, dan 9) Mendesak untuk mencapai kesepakatan pada hal-hal yang mendasar sebelum menerima penyelesaian.

Dengan aturan-aturan dasar tersebut, kampanye satyagraha selalu mengikuti sembilan tahapan berikut: 1) Negosiasi dan arbitrasi, 2) Persiapan kelompok untuk bertindak secara langsung, 3) Agitasi/pergolakan, 4) Mengeluarkan ultimatum, 5) Pemboikotan ekonomi dan bentuk pemogokan lainnya, 6) Tidak bekerjasama, 7) Ketidakpatuhan sipil, 8) Perebutan kekuasaan pemerintah, dan 9) Kesejajaran pemerintah.

\section{Kesimpulan}

Menyadari bahwa resolusi konflik penting dalam mendukung pekerjaan seorang guru. Prodi PGSD STKIP Weetebula menyelenggarakan atau menyediakan matakuliah khusus yang membantu calon guru untuk mengusai atau mempunyai kemampuan menyelesaikan konflik disekolah. Matakuliah dengan nama Manajemen Konflik, diajarkan selama satu semester dengan metode perkuliahan yang sering digunakan adalah metode praktik tentang model resolusi konflik disekolah. Ada empat garis besar materi yang yang harus dipahami oleh mahasiswa untuk menjadi guru yang bisa melakukan pendidikan resolusi konflik disekolah: 1) pengenalan akan konflik, 2) ketrampilan mediasi, 3) Komunikasi sebagai dasar perdamaian, dan 4) Pendekatan Religius atau agama dalam Pendidikan resolusi konflik.

\section{Referensi}

Arifin, Zainal .2013. Menjadi Guru Profesioanal (Isu dan Tantangan Masa Depan)12 (1.3)

Dokumen Kurikulum Prodi Pendidikan Guru Sekolah Dasar (PGSD) STKIP Weetebula.Tahun 2017.

Girard, K \& Susan J. Koch .1996. Conflict Resolution in the Schools_a Manual for Educations, United States: National Institute for Dispute Resulition and the National Association for Mediation in Education.

James, V.H. \& Owens, L.D. 2004. Peer Victimisation and Conflict Resolution Among Adolescent Girls in a Single-sex South Australian School. International Education Journal, 5 (1), 37-49.

Modul Tranformasi Konflik.2018. Buku Panduan: Transformasi Konflik Untuk dosen dan Pengajar. www.stkip-weetebula.ac.id

Lestari, M.2017. Rekonstruksi Pendidikan Awal Perdamaian Disekolah. Prosiding Seminar Bimbingan dan Konseling, 1(1), 267-279, Tersedia Online http://pasca.um.ac.id/conferences/index.php/s nbk ISSN 2579-9908

Wulandari, Taat. (2010). Menciptakan Perdamaian Melalui Pendidikan Perdamaian di Sekolah.Artikel dari MOZAIK Volume V No. 1 Januari 2010. 